\title{
Formation of the Native Philosophical and Logical Tradition in Theological Educational Institutions in the Second Half of the 16th - Early 18th Centuries*
}

\author{
Marina Ivleva \\ Faculty of Humanities and Social Sciences \\ Peoples' Friendship University of Russia \\ 6 Miklukho-Maklaya Str. \\ Moscow, Russia \\ E-mail: ivleva_ml@rudn.university
}

\author{
Vladimir Inozemtsev \\ Moscow State Technical University named after N.E. \\ Bauman \\ Financial University under the Government of the Russian \\ Federation \\ Moscow, Russia \\ E-mail: inozem_63@mail.ru
}

\author{
Vitaly Ivlev \\ Moscow State Technical University named after N.E. \\ Bauman \\ Financial University under the Government of the Russian \\ Federation \\ Moscow, Russia \\ E-mail: vitalijivlev@yandex.ru
}

\author{
Mikhail Oseledchik \\ Department of Philosophy and Social Sciences \\ High school of Printing and Media Industry \\ Moscow Polytechnic University \\ Moscow, Russia \\ E-mail: balu13@yandex.ru
}

\begin{abstract}
In this paper, the process of formation of the tradition of teaching philosophy and logic, which was called "Russian scholasticism", is studied. The phenomenon of "Russian scholasticism" is associated with the activities of Orthodox spiritual schools: fraternal schools that arose in the second half of the 16th century in the Lithuanian - Russian lands of the Polish - Lithuanian Commonwealth and appeared in the second half of the 17th century in the pre-Petrine era of the Kyiv - Mohyla Academy and the Moscow Slavic - Greek Latin Academy. Chronologically, this phenomenon covers the historical period from the end of the 16th to the beginning of the 18th century, when monastic education and scholarship, based on the personal practice of communication between the mentor (confessor) and disciples and aimed at forming the spiritual image of the pupil, comes to school scholarship. This is such a scholarship, in which a certain set of knowledge that is theologically oriented is broadcast, but it is not directly dependent on the teacher's personality.
\end{abstract}

Keywords-philosophy; logic; Russian scholasticism; spiritual educational institutions; Orthodox fraternal schools; Kiev - Mohyla Academy; Moscow Slavic - Greek - Latin Academy

\section{INTRODUCTION}

The ancient Russian wisdom did not have any special bias towards consistency; the native thought of this period, which did not trust the human intellect, gravitated toward the Logos - a category that included both the word, and the thinking, and the images. Most of the concepts, ideas, images

*The publication has been prepared with the support of the "RUDN University Program 5-100", and categories fundamental to the European culture of Hellenic civilization, Rus received from Byzantium as the main keeper of the ancient heritage. At the same time, unlike the West-European culture, the main language of which was Latin, the ancient Russian wisdom from the very beginning used its own language-the language of the Slavic pioneers Cyril and Methodius, who created the Slavic alphabet and translated the Bible. One can speak of Russian philosophy in the 11th -13 th centuries as a developed phenomenon; in the 14th -15 th centuries it is experiencing its bloom. At the same time, the main features of Russian philosophy of this period are its amazing inclusion in the context of culture, the relationship with literature, art (especially with icon painting and fresco painting), theology, exegesis, etc., expressed in the fact that philosophizing in Russia is not characterized by the translation of knowledge in conceptual-logical form. Ancient Russian wisdom is not the existence of knowledge about the world, expressed in categorical form, but the form of being in the world, the teaching of which includes not only "knowledge" (expressed mainly in the form of "dogmatism"), but also a "smart doing" and a deed.

In order to adequately understand the essence of the medieval philosophical worldview, it is necessary to remember its fundamental division into "internal" philosophy and "external" philosophy. If the first meant the love of Christian wisdom, especially the patristical, oriented toward the knowledge of God and salvation, then the second meant the love of worldly wisdom, especially the pagan, aimed at comprehending things of the world, lower in status than the first, but still important "for the correction of the 
mind". It is not by accident, for example, that John Damaskin, who was predominantly Aristotelian predominantly, was considered not only a revered hymnograph and theologist, but also a logician (it is enough to recall his "Dialectic"); however, the main direction of philosophy was still the syncretic perception of philosophy as wisdom, and not as a system of knowledge. The understanding of philosophy as practical, life-building, teaching not by word, but by the work of spiritual mentoring, as a way to heal the human soul, was rather a Christian interpretation of its Socratic understanding as a practical morality.

\section{II. "RUSSIAN SCHOLASTICISM" AS A PHENOMENON OF THE SPIRITUAL CULTURE OF THE PRE-PETRINE ERA}

In the era of the West European Renaissance and at the beginning of the New Time (17th century), with their orientation to the dignity and power of the human and not divine reason, a new trend is emerging in the native philosophical tradition, called "Russian scholasticism" (or "slavia scholasticism"). The authors of the article earlier turned to the study of the phenomenon of "Russian scholasticism" [1] [2]. This work continues to study this phenomenon.

The creative heritage of the representatives of the "Russian scholasticism", formed during the formation of professional humanities education in the Lithuanian Russian lands (this is due to the activities on the territory of the Polish - Lithuanian Commonwealth Orthodox fraternal schools, as well as the Kiev-Mohyla Academy and the Moscow Slavic-Greek-Latin Academy, later converted to the Moscow Theological Academy), is huge. Orthodox fraternal schools begin to appear in the Lithuanian - Russian lands of the Polish - Lithuanian Commonwealth from the end of the 16th century, and the taken basis is of the Western, more accurately the Latin-Polish model, which is far from being homogeneous. In the 16th century, Polish education was influenced by the ideas of Renaissance humanism and the Reformation. However, in the second half of this century, it is Poland that becomes the outpost of the counterreformation.

The main supporters of the counter-reformation in Poland were the Jesuits - convinced representatives of the Thomism, called from the time of the Council of Trent to be the main ideology of Catholicism. However, the Jesuit Thomism in the Polish colleges was largely different from the real teachings of Thomas Aquinas, based on the need to search for harmony between faith and reason, between the Bible and Aristotle, between creature and Creator. The Jesuits sought to educate faithful sons of the Roman Catholic Church, who were ready to submit their reason to its authority, serve its interests and protect them in their schools. The "true" scholastic theology was put at the head of the teaching, to which both philosophy and science were to submit, while philosophy was interpreted in the spirit of "true scholastic theology" and the basis for philosophical education was the adherence to the authority recognized by the Catholic Church. Due to this requirement, the professor of philosophy should neither introduce new opinions nor interpret new questions, the basis of which could not be found in authoritative philosophers, nor defend anything contrary to these authorities - Thomas Aquinas and Aristotle.

Thus, the system of education recommended by the Jesuits did not meet the general humanistic requirements of the era, being an example (and not the best one at that) of the Catholic counter-reformation. Meanwhile, it was the Polish education in the form in which it was formed during the period of the Catholic counter-reformation, that had a huge impact on the formation of Russian education in the 16th17 th centuries - the Latin-Polish Jesuit schools offered such an education system that could become the basis for the struggle undertaken by Orthodox brotherhoods against the Jesuits themselves. In addition, the cosmopolitan nature of Polish schools proved to be as resonant with the profound transformations within the Russian consciousness itself as possible.

Until the end of the 16th century, the general level of education of the population of the Lithuanian-Russian lands was quite low; schools were few, and in those training was limited only to the ability to read church and liturgical books, and write. Only since the time of the Lublin Union and the appearance of Jesuits in the Lithuanian-Russian lands, when the intensified propaganda of Catholicism began to seriously threaten Orthodoxy, the awareness of the need for scientific education began to gradually form in the South Russian academic community. At the same time, non-Orthodox educational institutions, especially Jesuits, were famous for their scientific forms of teaching (including the Latin language, which was the universal language of science at the end of the XVI century) and the profound erudition of its professors. The educated inhabitants of the Russian lands of the Polish - Lithuanian Commonwealth were threatened by the serious danger of losing their own religious identity.

The result of realizing this danger is the establishment of Orthodox fraternal schools in Ostrog, Lviv, Vilna and a number of other towns of the Polish - Lithuanian Commonwealth. The prototype of such schools was Lvovskaya, and according to its model other schools were created in those cities of western and south-western Russian lands, where dependence on Polish influence was felt most strongly. From the very beginning, these schools have had a huge advantage over other schools - above all else, an advantage of a legal and organizational nature.

The programs of the sciences taught in the fraternal schools were fixed in the patriarchal and royal Charters given to these schools, called as Greco-Latin-Slavic. From these Charters it followed that the pupils of schools were taught not only reading and writing, but also completed their education with a report of philosophical and theological information. It should be noted that the sciences of the philosophical variety were introduced into the teaching gradually, and sometimes they were superseded by purely philological disciplines.

So, in the oldest of the fraternal schools - Lviv - at the beginning of its existence pupils were only taught to read and write. Then, with the blessing of Patriarch Joachim in 1586, the teaching of Greek and Slavic languages was opened. 
There is evidence that before 1620 in the Lviv fraternal school they taught Russian grammar and Latin literature, after 1620, with the blessing of Patriarch Theophanes, the Greek and Polish languages were introduced into the circle of teaching [3]. A similar scientific program existed in other brotherhood schools.

The composition of the sciences studied in schools goes back to the traditional scholastic division into the "seven noble arts": grammar, rhetoric, dialectics, arithmetic, geometry, astronomy and music. Within the framework of this work, the only discipline of interest is dialectics due to its philosophical nature. Unfortunately, not a single dialectic textbook taught in fraternal schools has survived, but according to some documents it can be established that this discipline was different from logic in the narrow sense of the word.

\section{SPECIFICITY OF EDUCATION IN THE PETRINE ERA}

With the onset of Petrine reforms, education becomes secular. If, one of the main tasks of the brotherhood schools was to form a system of knowledge that allows one to survive in a situation of a permanent Roman Catholic intellectual expansion, then the goals of the Petrine era were different. It became obvious that while using traditional literacy it was impossible to inculcate and develop European enlightenment, to acquaint people with the range of natural scientific ideas, the basics of mathematical and technical knowledge.

Embarking on the reform of the national education, Petrine administration showed itself to be a supporter of an extremely utilitarian approach. Due to this, the Petrine administration paid special attention to the organization of the middle type of special educational institutions. The Artillery and Navigational Schools of J. Bruce and A. Farvarson, which opened in 1701, the medical school of Dr. N. Bidloo that started training in 1707 , as well as the "tsifirnye schools" that appeared in the Russian pedagogical space by decree of February 28, 1714 year, did not give anything, except for the initial special-technical education. So, in the Navigational School, classes began with literacy. The pupils of raznochintsy were taught reading, writing, counting, and then sent as assistants to healers, or sent to the chancery. As for the nobles, they continued to engage in geometry, trigonometry, navigation, astronomy and geography - the sciences of a naval officer. After the death of Peter I, these schools collapsed, which becomes obvious from the report of the Admiralty College to the Senate, marked in 1750: "Pyotr's favorite brainchild", "navigational science", "sorrowfully fell" V. O Klyuchevsky, sadly resounds on this matter [4].

At the first stage of educational reforms, various foreign educational institutions, many of which were in Moscow, were of great importance. First of all, it is necessary to mention the school, headed by a probst E. Gluck's, after whose death in 1705 the school was headed by V. Pauz. In addition to the simple subjects that formed the circle of primary education, the Lutheran mentors planned to acquaint their pupils with the "Cartesian philosophy". The Jesuits, who held a competing educational institution in Moscow, taught Latin, mathematics and military science. Even in the distant Tobolsk for a time being there was a school of a captured Swedish officer von Wrex. As national educational institutions got up on their feet, the need for foreign schools had naturally withered away. This process dragged on - so, in the era of Alexander I, the Jesuit schools in St. Petersburg attracted crowds of highborn young ignoramuses into their walls [5].

Secondary special educational institutions did not fill the lack of higher schools, namely universities and the academies where, among other subjects, philosophy would also be taught. Attempts to create such an academy have been traced since the beginning of the XVII century, when Boris Godunov was trying to invite some German teachers to Russia, but he still had to abandon this idea because of the opposition from the clergy. In 1632 an attempt was made in Moscow to create a school with a full humanitarian education. Thus, Adam Olearius testifies to the existence of a certain school of Arsenii Grek in 1634. Notable milestones on the path to the formation of academic philosophy were: the establishment of the Greco-Latin school at the Patriarch's court, better known in history as Rtishchevskaya (the time of activity 1648-1673), the opening of the Spassky school (operated from 1665 to 1667) and, finally, the organization of the Typographic and Epiphany Schools (from 1682 to 1685). In the above-mentioned educational institutions, the sciences were not systematically presented; the students received only fragmentary, superficial knowledge, which is why the activity of the named schools gradually fades with the opening of the Moscow Slavic-Greek-Latin Academy [6]. All this had to affect the nature of the teaching of philosophical knowledge, including logical knowledge. Professional philosophical education in Russia originates from lectures read in the walls of Kyiv-Mohyla and Moscow Slavic-Greek-Latin academies.

\section{KYIV-MOHYLA ACADEMY AND ITS ROLE IN THE DEVELOPMENT OF THE RUSSIAN PHILOSOPHICAL AND LOGICAL TRADITION}

Mainly carrying out the function of preserving the purity of the Orthodox faith, pre-Mohyla schools could not compete with heterodox colleges on the quality of education, i.e. they did not fulfill their immediate task: to be carriers and subjects of enlightenment. This educational task was carried out only with the formation of the Kiev-Mohyla Academy [7] [8] [9] [10] [11] [12]. Appeal to the writings of the professors of the Kiev-Mohyla Academy is also natural, because since the very creation of this academy, philosophy is taught in it and is made a scientific discipline along with other sciences. Although it should be noted that a certain attempt to present philosophical knowledge was made in the Ostroh Academy, in brotherhood schools of the PolishLithuanian Commonwealth and in schools at large monasteries in Moscow Rus. But only in the Kiev-Mohyla Academy, philosophy becomes a systematically taught discipline.

The founding of the Kyiv-Mohyla Academy as a higher educational institution dates back to 1632 (after the merging 
between the Kyiv Brotherhood and Lavra schools, before that and up to 1701 this educational institution was called the Kiev College). Founder of the Kiev Academy Peter Mogila was an outstanding figure in Ukrainian culture, a prominent educator, philosopher, and theologian. In this academy (college), grammar, rhetoric, dialectics, arithmetic, music, geometry, astronomy and theology were mandatory disciplines. The Academy also successfully taught Latin, Greek, Hebrew languages, geography, mechanics, psychology and medicine.

The main method of teaching in the academy during the 17 th century was the scholastic method. However, the very phenomenon of the formation of "Russian scholasticism" as a special form of Russian scholarship is rather demonstrative: it is the rationalism and enlightening character of teaching in the academy that transforms the concept of knowledge, making it an instrument (including inter-confessional struggle). The school gave its pupils a thorough knowledge of the Latin language - the universal language of science; In addition, rhetoric exercises significantly influenced the formation of the literary language, while the study of philosophy had accustomed them to mental work, consistent thinking and precision of definitions.

Among the professors of the Kiev Academy, manuscripts of whose courses have reached our time, the most notable are Innocentius Gisel, Joasaph Kryukovsky, Stefan Yavorsky, Theophanes Prokopovich, Christopher Charnutsky, George Konissky. Traditionally the research literature has are two main directions within the framework of the Kiev-Mohyla Academy. First one is the conservative direction (Stefan Yavorsky, Christopher Charnutsky and Gideon Vishnevsky), in which the scholastic influence was stronger. The second is the scientific and educational direction (Theophan Prokopovich, Gabriel Buzhinsky, Mikhail Kozachinsky and Georgy Konysky), where the intentions of the New Age are more noticeable. The general dynamic movement "from the Logos to logic", that is characteristic of this era as a whole, is quite clearly expressed in the philosophical courses of the representatives of both the first and the second directions.

If we try to evaluate the philosophical courses of the professors of the Kyiv-Mohyla Academy as a whole, then the scholastic components of these courses (primarily a form connected with numerous distinctions and definitions, references to the Bible, the writings of the holy fathers and Aristotle) are obvious enough, just as the novelty of their content. The criticism of Thomism that they contained, just as in many cases other trends of the second scholasticism, was directed against philosophical and theological teachings, that were often used as "ideological weapons for the duration of Catholic expansion", which undoubtedly contributed to the formation of the self-identity of the Russian inhabitants of the Commonwealth as Orthodox people, capable of resisting this expansion [13].

In addition, the inevitable rationalization of knowledge, that was carried out through the school teaching of the humanities (and theological disciplines), was - during the historical period of the turn of the 17 th -18 th centuries and the Peter's reformations - already a project of the New time, with its orientation on the values of reason and enlightenment. It is in these philosophical courses taught at the Kiev-Mohyla Academy that were reflected already begun, but still far from complete, processes of demarcation of theology and philosophy and the constitution of philosophy as a special discipline. Finally, within the framework of the academic philosophy of the 17 th century, the problem of the method is first actualized - a problem that is important to the entirety of philosophy of the New Age. Traditional scholastic metaphysics are gradually losing their position; rhetoric and logic are being put forward to the role of the methodology of the humanities.

\section{FORMATION OF THE MOSCOW SLAVIC-GREEK-LATIN ACADEMY AND THE BEGINNING OF RUSSIAN ACADEMIC PHILOSOPHY}

The Moscow Academy in many respects was similar to the Kyiv-Mohyla Academy, whose activities in the formation of professional philosophical education in Russia cannot be overestimated. The question of the date of the opening of the Moscow Academy is still disputed to this day. Individual researchers take 1985 as the original date, since that's when the school was officially recognized by the patriarch Joachim. Other historians have been counting since 1687 , as it was then that the construction of the building in the Zaikonospassky Monastery was completed, and lasted until 1814. It is generally accepted that the history of the academy is divided into three stages. The first of them (1685 - 1700) is associated with the names of Greek teachers, the Likhud brothers. The second period $(1700-1755)$ is dominated by Latin influence. The third period (1755 - 1814), marked (since 1775) by the activities of Metropolitan Platon (Levshin), is characterized by increased impact of the church, which led to the transformation of the academy into a purely theological educational institution [14] [15] [16].

The first stage of the Academy's existence is associated with the names of Greek teachers, brothers Ioannikia and Sofronia (secular names - John and Spiridon) Likhud. The Likhud brothers were extremely educated people for their own time. They were trained in philosophy and theology in Venice. Then they continued their education in Padua, where they received doctoral degrees. Since 1670 - the year of their consecration into the hierarch's rank - the brothers conducted active teaching activities first on the territory of Greece and Italy. In the middle of 1680 Likhud brothers moved to Moscow, where they had founded the Hellenic-Greek School, later renamed the Slavic-Greek-Latin Academy, designed, according to its organizers, to combine the form of a traditional Western European university with the spirit of the Orthodox Academy.

In the first year of training in the school there were only five students: Alexey Barsov, Nikolai Semenov-Golovin, Theodore Polikarpov, Theodor Aggeev and Joseph Afanasyev [17]. Trying to beware of "wisdom inconsistent with Orthodoxy", the Likhud brothers followed the usual scholastic tradition and focused on Aristotle, although not in the Latinized Latin variant, but in the Orthodox Greek version, which originated from the holy fathers of the Cappadocian school and Damascene. In 1690, Sofroniy 
Likhud announced to his students that he would teach logic, following throughout Aristotle; physics lectures relied on the physics of Aristotle). At the same time, philosophy is defined by Ioannicius in the following way: it is "the understanding of understanding, the spoken art of arts, preached knowing of knowing and with the fear of the Lord is determined" [18].

Active pedagogical practice made it possible to lead an ideological struggle against the party of "latinudurs". Ioannikiy and Sofroniy Likhud, left behind many polemical works. Historically, this controversy ended for Likhud brothers with more of a victory than a defeat: the government of Princess Sophia, patronizing the education of the LatinPolish model, fell; The new government did not manage to come up with a more or less specific program, and Patriarch Joachim was a staunch opponent of Latin-Polish and Southern Russian education, which served in the Kiev school as a tool for intrigues of the Little Russian clergy against his Moscow authority [19].

It was thanks to the assistance of the patriarch that Likhuds managed to get the rectorship at the academy. In addition, adherents of Orthodox Greek education were also supporters of the famous Orthodox-political theory of Moscow being the third Rome, opposed both to the Latin and Old Believers. Insisting on the purification of Russian Orthodoxy from distortions, they thereby strengthened the grounds on which the international significance of the Moscow state and the sovereign was kept.

In general, the philosophy of the Likhud brothers can be characterized as prone to transcendentalism; it was mostly creationist [20]. This was reflected in the fact that the Likhuds distinguished two ideal, non-existent principles of natural things. The outer principle was considered transcendental to the earthly world, while the inner one was immanent. The first, identified with God, was regarded as a fixed prime mover, propelling everything that exists in nature, while the second, that was dependent on the first, fulfilled the distributional functions in the becoming, real being. The question of the extent to which the Likhud brothers experienced the influence of averroism - (averroism, as a philosophical trend, existed at the University of Padua (which Likhud brothers graduated), throughout the 17th century) - is still open, due to insufficient knowledge of the philosophical courses belonging to the founders Moscow Academy.

\section{CONCLUSION}

The active influence of the culture of the West, the culture of the New Time, for which the instrumental perception of the understanding is characteristic, made the study of philosophy as a science of the method and knowledge, and also logic as an auxiliary philosophical discipline studying the methods of correct reasoning, relevant to the era of Peter's transformations. During this period, philosophy and logic began to be actively taught as special disciplines in the early Orthodox brotherhood schools in the Lithuanian-Russian lands of the Commonwealth, and later in the Kiev-Mohyla and Moscow Slavic-Greek-Latin academies.

\section{REFERENCES}

[1] V. Yu. Ivlev, Logic in Russia. The first half of the XVIII century. M.: Kogito Center, 2000.

[2] V. Yu. Ivlev, M. L. Ivleva, Peculiarities of Aristotelian scholastic logic // "Proceedings of the 2017 2nd International Conference on Contemporary Education, Social Sciences and Humanities". (ICCESSH 2017). Part of the series ASSEHR. Moscow, Russia., pp. 91-95.

[3] Annals of Zubritsky // Journal of the Ministry of Public Education, 1849, No. 4, pp. 15 - 20; No. 5, p. 64.

[4] V. O. Klyuchevsky, Course of Russian History // Works: In 9 volume,V.5. M., 1898, p. 149.

[5] A. V. Florovsky, Latin schools in Russia in the era of Peter the Great / Eighteenth century. M.; L., 1962. Sb.5, pp. 316 - 335.

[6] V. S. Rumyantseva, Rtishchevskaya school // Questions of History, 1983. No. 5, pp. 179 - 184.

[7] V. Ascochensky, Kiev with the oldest school of his Academy. Part 1. Kiev, 1856.

[8] M. Bulgakov, History of the Kiev Theological Academy. St. Petersburg, 1843.

[9] D. Vishnevsky, Kiev Academy in the first half of the XVIII century. Kiev, 1903.

[10] S. Golubev, Kiev Metropolitan Peter Mohyla and his Companions. V. 1. Kiev, 1883.

[11] N. Petrov, Kiev Academy in the second half of the XVII century. Kiev, 1895.

[12] N. Sumtsov, To the history of the South-Russian literature of the XVII century. Issue. II. III. Kiev, 1884.

[13] V.M. Nichik, The main directions of philosophical thought in the Kiev-Mohyla Academy. Kiev, 1978, pp. 9 - 10.

[14] S.K. Smirnov, The history of the Moscow Slavic-Greek-Latin Academy. M., 1855.

[15] S.N. Bratilovsky, Essays from the history of enlightenment in Moscow Rus in the XVII century. St. Petersburg, 1902.

[16] Makarios Metropolitan, History of the Russian Church. St. Petersburg, 1882. V. 11.

[17] S. K. Smirnov, The history of the Moscow Slavic-Greek-Latin Academy. M., 1855, p. 24.

[18] A. Smelovsky, The Likhud brothers and the direction of the theory of literature in their school / / Journal of the Ministry of Education, 1845 No. 3, p. 81 .

[19] S. Ternovsky, The study on the subordination of the Kiev Metropolitanate to the Moscow Patriarchate // Archive YuZR, Kiev. 1872. V.5, pp.111 - 169.

[20] Y. M. Stratiy, Problems of natural philosophy in the philosophical thought of Ukraine XVII. Kiev, 1988, p. 32. 